secretaries and other members of the committee, a sum of $\delta 1,500$ has been subscribed: much more, however, will be required in order to carry out the wishes of the promoters of the "Sharpey Memorial" scheme.

Having held his present professorship since 1836 , Dr. Sharpey is well known to, and as thoroughly esteemed by, a very large number of old students, who have not only experienced the benefit of his clear, logical, and thorough method of teaching, but have felt the genial influence of his kindly sympathy, and the value of that breadth and soundness of judgment for which he is so remarkable. The large majority of his old and present students will now doubtless be delighted to take part in a movement destined to do honour to their favourite professor: and we believe that many of those who have been associated with Dr. Sharpey in his various official capacities in connection with science and education will also gladly avail themselves of this opportunity of testifying to their high appreciation of the valuable services which he has performed in both these capacities, and also of bearing witness to the strong feelings of personal regard with which he has inspired them.

The proposed memorial is of a nature likely to be peculiarly gratifying to Dr. Sharpey. The future "Sharpey Physiological Scholar" is destined to work in the Physiological Laboratory of the College, in the practical departments of the science; and successive students who may obtain this honourable distinction will, it is hoped, come for some time under the immediate supervision of Dr. Sharpey himself. The Professor has most liberally offered to present to the College his anatomical and physiological library, consisting of the best works of the older anatomists, a useful series of foreign scientific periodicals, and a large number of monographs by some of the most active and learned observers of modern times. It is proposed to place these books in a new class-room for practical physiology, which is about to be fitted up under the name of the "Sharpey Physiological Laboratory and Library;" and which, as part of the memorial, is to be adorned by a portrait of the man to whom the subscribers wish to do honour now, and whose memory they desire to perpetuate in the future. If the amount of the "Memorial Fund" is sufficient, it is also proposed that a bust of Dr. Sharpey should be executed for presentation to the College. The plan seems an excellent one, combining as it does the feature of being a thorough personal tribute of the most gratifying nature to Dr. Sharpey, destined to convey to successive generations of students a notion of the high estimation in which his services in the cause of science and education were regarded by his contemporaries, whilst it is also a movement likely to result in the further extension of that branch of science to which he has himself principally contributed. It is hoped that the study of practical physiology will thus be helped on more than it has hitherto been in this country, and that in time a school of practical physiology - the precursor of many others-may be established, equal to any of the now celebrated continental schools. It is expected that many of the fellows of the Royal Society and of other scientific bodies will gladly take this opportunity of doing honour to a man whom they all esteem so highly, and for whom so many entertain warm feelings of personal regard. We are glad to find that several of the foremost amongst them have already given evidences of substantial co-operation, and we trust that many others will follow their example.

\section{THE ISTHMIAN WAY TO INDIA}

THE Canal has been opened. The flotilla, with its noble, royal, imperial, and scientific freight, has progressed along the new-made way from sea to sea. From Port Said, that new town between the sea and the wilderness, with its ten thousand inhabitants, and acres of workshops and building-yards, and busy steam-engines, the naval train floated through sandy wastes, across lakes of sludge and lakes of water filled from the Salt Sea; past levels where a few palm-trees adorn the scorched landscape; past hill-slopes on which the tamarisk waves its thready arms; past swamps where flocks of flamingoes, pelicans, and spoonbills, disturbed by the unwonted spectacle, sent up discordant cries; through deep excavations of hard sand or rock; across the low flat of the Suez lagoons, where Biblical topographers have searched for the track of the children of Israel; and so to the "red" waters of the great Gulf of Arabia. The flotilla has done its work : the Canal has been opened ; and the distance by water to India is now 8,000 miles, instead of the 15,000 miles by the old route round the Cape of Good Hope.

It is a great achievement. So great, that we need not wonder that the capital of $8,000,000 l$. sterling with which it was commenced in I 859 was all expended, and as much more required, before the work was half accomplished. And perhaps we ought not to be too much overcome with pity for the 20,000 unlucky Egyptians-natives of the house of bondage-pressed every month up to the year I 863 by their paternal Government to labour, wherever required, along the line of excavations. How persistent are Oriental customs! Here we have in modern daysthe days of power-looms, of steam printing-presses, and under-sea telegraphs-a touch of the old tyranny, the taskmasters and the groanings, associated in our memories with the very earliest of Egyptian history.

The length of the Canal is one hundred miles, and the depth, as the French engineers inform us, is to be everywhere twenty-eight feet, so as to admit of the passage of large vessels. It must not be supposed that an excavation of the depth above mentioned has been dug all across the Isthmus, for the level of the country is, for the most part, below that of the Mediterranean; consequently, miles of banks have been thrown up across the lowest tracts to form a channel for the water. In looking at a section of the whole route from Saïd to Suez-seventy-five miles in a direct line from sea to sea-the great extent of depression is well seen. In Lake Timsah it is about eighteen feet; in the Bitter Lakes, which stretch to a length of twenty-five miles, it is in places twenty-six feet. On the other hand, the elevations, though comparatively few, are somewhat formidable of aspect, particularly at $E \mathbf{i}$ Guier and at Chalouf. The more this section is studied, the more forcible becomes the impression on the mind that a strait thickly studded with islands, as Behring's Strait, once separated Asia and Africa, and that by the drift from the Nile and the desert the sea has been filled up around the islands, with the exception of the lake depressions, until the present Isthmus was formed. Hence the difference of soil. The islands rising boldly up : El Guier, ten miles long, layers of sand and hard clay; Serapeum, three miles long, a kind of shelly limestone; and Chalouf, six miles long, composed of hard clay, sandstone rock, and conglomerate, the severest part of the excavation. Geologists have remarked upon the fact that the fossils found in the Chalouf ridge are identical with those of the London basin and the hill of Montmartre, whereby we learn that parts of Egypt, France, and England are of the same age.

The mountains of Abyssinia are every year diminished in size and height by the enormous periodical rains which wash down millions of cubic feet of mud and clay into the Nile. Vast clouds of sand are blown into the great river in its long course through the deserts; and these transported matters, caught by the strong current setting. in from the Straits of Gibraltar, have been drifted to the eastward during immemorial ages, with consequences which are well known to those who have studied the geography and geology of the Isthmus. Such a transformation will be recognised as one of the ordinary operations of nature, when we remember that in 4,150 years the valley of the Nile has been raised eleven feet by 
deposits from the periodical floods, and that the land of Egypt is supposed to have been at one time a gulf stretching from the Mediterranean towards the Mountains of the Moon, but which became silted up by slow accumulations.

We may now form a clear notion of the region through

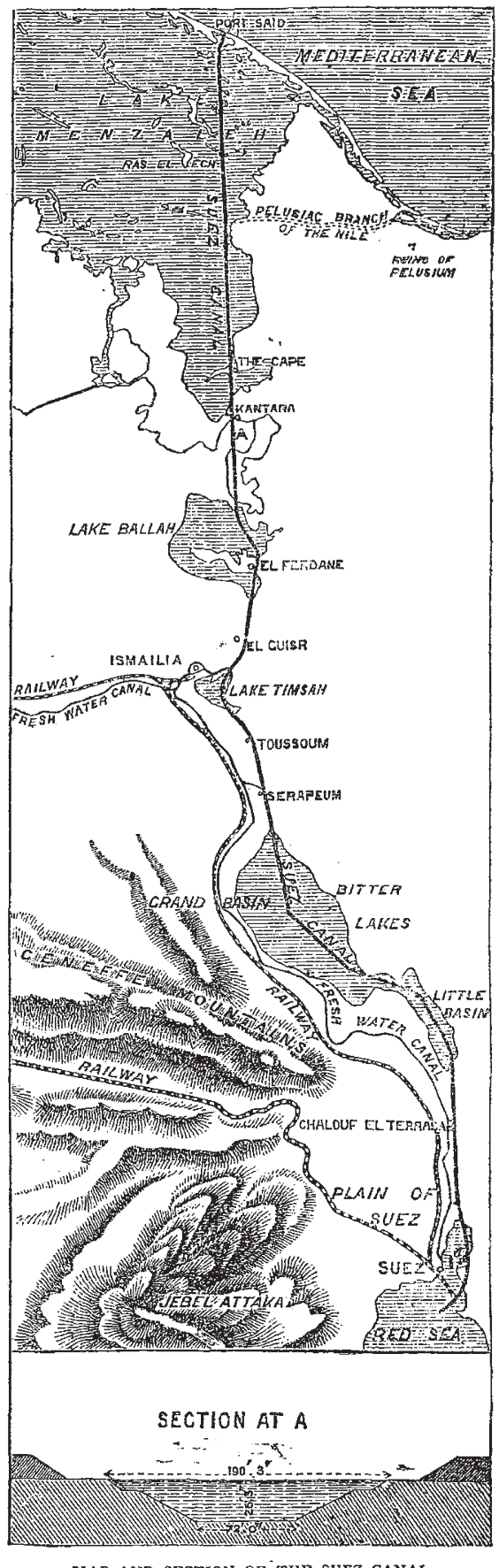

MAP AND SECTYON OF THE SUEZ CANAL

which the Canal has been cut. A low, sandy shore is generally washed by a shallow sea. At Southend the pier extends for a mile and a quarter into the sea before meeting depth enough for an ordinary steamer; and the long piers at Lowestoft and other places on our eastern coast present themselves as illustrations in point. So shallow is the sea off Port Said, that the mouth of the harbour had to be commenced two miles from the shore, for there only did the required depth of twenty-six feet of water begin. Less than this will keep out vessels of the largest class. The western pier, the one against which the whole weight of the powerful current falls, projects more than two miles into the sea; the one to the east is half a mile shorter. These breakwaters have been built up of concrete blocks weighing twenty tons each, made on the spot from the sand dredged out of the harbour mixed with hydraulic lime brought from Marseilles. Spaces were left between the blocks to be filled up by the seadrift; but though there have been great deposits of sand and mud outside the breakwater, the filling up of the gaps has not been so speedy as was anticipated, and heaps of sand which drifted through have had to be dredged out again. of course, while money for payment is forthcoming, any number of dredging-machines may be employed; but can that process be depended on when enthusiasm shall have evaporated, and there is nothing but the prosaic work of letting ships in or out to animate the promoters? Will it always be possible to prevent the formation of such soft banks as that on which the "Prince Consort" and the "Royal Oak" grounded on their arrival to take part in the opening of the Canal?

There is something instructive in the operations which have so diligently been carried on at the mouth of the Tyne, where a passage through the bar is essential. To maintain this passage, eighteen feet deep only, more than four million tons of sand must be dredged out every year. This has been going on for ten years or more, and the channel is not yet secure.

Not only the harbour of Port Saild, but the greater part of the Canal itself, has been formed by dredging; and this, in soft ground or through the sludge of Lake Menzaleh, was comparatively easy work. The mud raised from the bottom was spread along each margin of the newlyscooped-out channel; but it would not stay there, and for a time the prospect of maintaining an open channel seemed as hopeless as George Stephenson's first attempt to carry the Liverpool and Manchester railway across Chat Moss. No sooner was the Menzaleh mud deposited in its new position, than it either slipped back into its former bed, or squeezed the soft soil on which it lay into the channel. The dredgers were in despair over a task in which no progress could be made, until one day one of the labourers showed that if, instead of great heaps, a thin layerr of the mud were spread and left to harden in the sun, it would not slip back. So layer by layer the mud was spread, the banks were built up, and a way for the Canal was opened through such slime as was used in ancient days for the making of bricks.

In the hard ground the "bondagers" dug with pick and spade, and carried away the loosened soil in baskets. But when they were supplemented by European labourers, powerful excavating machinery was employed, and the line of works presented as busy a spectacle as an English railway in course of construction, or the main drainage works in their progress towards Barking Creek across the Essex marshes. The slopes of the cuttings were alive with labourers and machines, by which the excavated earth was lifted and run off to a distance. The power of the digging-machines may be judged of from the fact that some of them could dig out 80,000 cubic metres of soil every month, and that on one occasion the quantity was 120,000. A dozen or two of machines working at this rate would soon make a big gap through the high grounds before them.

The lakes of water on the Isthmus may be regarded as Nature's contribution towards the success of the Canal; for in them the only labour required is to dredge a channel which will give a depth of twenty-eight feet. Moreover, they may be used as ports. This is especially the case with Lake Timsah, on the shore of which stands the newly-built 
town of Ismailia, the half-way stopping place for travellers on the Canal. Here anchored the flotilla during the progress of the opening, and the dark-skinned children of the Prophet were seen mingled with throngs of fair-complexioned Giaours in friendly rejoicings.

Ismaillia is an important place, for it is the pumpingstation of the fresh-water canal which was first made in order to supply the thousands of labourers with drink, and water for their works. On this pumping-station all the country between Lake Timsah and Port Saïd depends for it supplies of the precious element.

The hollow of the Bitter Lakes, six miles wide in the widest part, is believed to have been at one time connected with the Red Sea. The level of the water in these lakes has been brought up to that of the sea by a re-opening of the connection. In March of the present year, all preparations being complete, the water was admitted, and a great stream, pouring in from the Mediterranean and from the Red Sea, gradually rose upon the arid saline slopes of the deep and desolate basin. For some weeks the flow went on, until, as was estimated, two thousand million cubic metres of water had flowed in, and the level was established. The area of the lakes will be largely increased by this contribution from the two seas; and it will be interesting to watch whether in connection with the two canals-the salt-water and fresh-water-any modification of the climate of the Isthmus may be.produced. Much has been said, too, about the loss that will take place by evaporation under the sun of Egypt: the amount is so great as to be almost incredible. This loss will have to be provided for ; as also the effect of blowing sands, which will accelerate the tendency of the bottom to grow towards the surface, always observable in canals.

$\mathrm{Up}$ to the last moment predictions from various quarters have been heard that no big ships would ever effect the passage of the canal. But while we write these lines, telegrams from the East inform us that L'Aigle, the French yacht, with her Majesty the Empress on board, had got through, and was anchored in the Red Sea. From the same source we'learn that the Peninsular and Oriental steamer Delta, drawing $15 \frac{1}{2}$ feet of water, had arrived at Ismailia from Port Saïd, but had touched ground a few times on the way. The Egyptian vessel Lattif attempted the passage, but for want of sufficient depth had to return; difficulties occurred with other vessels, and the banks of the Canal were much damaged.

But the Khédive has invested M. de Lesseps with the Grand Cross of the Order of the Osmanli, and the Emperor Napoleon has appointed him to the rank of Grand Cross of the Legion of Honour. We may therefore hope for the best in all that appertains to the Suez Canal, and that foreigners will believe that Englishmen are too ready to admire good work to feel jealous of the energetic hearts by whom it has been accomplished.

\section{LETTERS TO THE EDTTOR \\ [The Editor does not hold himself responsible for opinions expressed by his Correspondents. I \\ The Meteor of November 6th}

METEORs being in season just now, all facts respecting them will, I presume, be acceptable. The public have lately been treated to a great number of letters in newspapers descriptive of the remarkable meteor of Saturday, November 6th-perhaps I should rather say $a$ instead of the remarkable meteor, because, from the discrepancies as to the time of the appearance and the differences in the description, I am inclined to believe that more than one meteor of unusual splendour was seen on that evening. I need hardly say how important it is to have observations of the visual direction of these bodies as viewed from stations widely separated from each other, because it is only observations of this kind which can afford clata for judging of the distance of a meteor. In the hope of contributing information which may assist in clearing up this interesting question, I venture to add another letter to the many which have already appeared.
At five minutes before seven on Saturday evening, November 6th, while walking with my back towards the south, near the village of Rothbury in Northumberland, I was startled by a brilliant light behind me, and on turning I saw a magnificent meteor descending from the eastward at an angle of about $45^{\circ}$ to the southern horizon. Its colour was a bluish-white, and it left a train which looked exactly like that of a large rocket, but which did not remain visible to my view for more than about fifteen seconds. The meteor did not appear to me to burst, although pieces seemed to separate from it before it expired. At the moment of extinction it was about $12^{\circ}$ or $14^{\circ}$ above the horizon, and its direction was then S.S.W. I am quite sure as to the time of the occurrence to within a minute, because, although I could not see to read my watch at the moment-a chronometer on which $I$ can depend, and which $I$ know was right -I hastened to the nearest light, about four hundred yards distant, where I ascertained that the time was one minute to seven, which, allowing about four minutes for walking the four hundred yards, would make the time of the appearance five minutes to seven. So far as I have seen, there is but one describer of this meteor whose record of the time exactly agrees writh mine, and as it is incredible that two such unusual meteors should occur in the same minute, it is almost absolutely certain that he and I saw the same. My co-observer was the writer of a letter in the 7imes, signed J. A. Cayley, dated from the neighbourhood of Bristol, where he witnessed the phenomenon at a distance of two hundred and sixty miles from where I saw it in Northumberland. As viewed by him, it appeared to descend from the zenith to about $20^{\circ}$ above the western horizon, while I, as already stated, saw it in the south. His description of the meteor differs from mine only in regard to the train, which is clescribed as continuing visible to him for fifteen minutes, a difference which may be attributed to its being nearer and more overhead to him than to me.

I will not hazard even an approximate calculation of distance from the data I have given, but I confess my inability to reconcile the different angles under which this object was seen at opposite ends of a base-line having Bristol at one end and Rothbury at the other, with the supposition that its height did not exceed that which is ordinarily assigned to the atmosphere. At all events, if the atmosphere exists at the height of this meteor, it will be more attenuated than in the exhausted receiver of the most perfect air-pump, and it is difficult to conceive how air so rarefied can so oppose the flight of a solid body as to produce the intense ignition exhibited in a meteor. Yet it seems impossible to attribute the incandescence of these bodies to any other cause than the resistance opposed by the atmosphere to their prodigious velocity.

\section{Newcastle-on-Tyne, Nov. 22, 1869}

\section{Lectures to Ladies}

No one can appreciate more heartily than I do the excellent article on "Lectures to Ladies" which appeared in NATURE No. II.; but I feel far from sanguine of success attending the efforts there referred to. If we put aside the impulse of dilettantism and the spirit of rivalry as against men, there will, let us hope, be left a very fair residue in the shape of love of learning, for learning's sake, as a reason for attendance; and it is only this pure love of learning which can make such lectures in the long run successful. It cannot, however, be such a love which brings to the lectures of the University College Professors, Lady Barbara, who sneers aloud when the lecturer wisely lays a sure foundation of elementary facts and ideas ; or which carries to South Kensington the Hon. Miss Henrietta, who tosses her head when she finds the great Mr. Huxley paddling about in that common river the Thames, and treating his audience as if they were little girls at the Finsbury Institution.

I very much fear that the Lady Barbaras of the present generation are beyond redemption, and that many earnest men are wasting their strength in trying to win the minds of intellectual coquettes.

There is an order of women, however, having in their number, as I know full well, some of the brightest and best of the women of England, to whom such lectures would be as manna in the wilderness. To women struggling, as many of us are, to get their daily bread by the hard task of teaching, and in the struggle getting glimpses of the sweetness and the light of real knowleclge, the chance of listening to real teachers would be an inestimable boon. These are the women to whom, it mist be remembered, 